\title{
EXPERIENCES OF HEALTH CARE PROVIDERS MANAGING SEXUAL ASSAULT VICTIMS IN THE EMERGENCY UNIT Part 2: Discussion of Results ANd literature CONTROL
}

Authors:

Rebecca M. Skhosana

Mmapheko D. Peu ${ }^{2}$

\section{Affiliations:}

${ }^{1}$ Department of Health, Mpumalanga Province, South Africa

${ }^{2}$ Department of Nursing Science, University of Pretoria

Correspondence to: Mmapheko D. Peu

e-mail:

doriccah.peu@up.ac.za

\section{Postal address:}

PO Box 667, School of Health Care Sciences, University of Pretoria, Pretoria 0001, South Africa

\section{Keywords:}

patient-carer relationship; sexual assault; victims; health care providers; emergency unit

\section{Dates:}

Received: 05 Nov. 2008 Accepted: 21 July 2009 Published: 17 Sept. 2009

How to cite this article: Skhosana, R.M. \& Peu, M.D., 2009, 'Experiences of health care providers managing sexual assault victims in the emergency unit Part 2: Discussion of results and literature control', Health SA Gesondheid 14(1), Art. \#481, 5 pages. DOI: 10.4102/ hsag.v14i1.481

\section{This article is available} at: http://www.hsag.co.za

(C) 2009. The Authors. Licensee: OpenJournals Publishing. This work is licensed under the Creative Commons Attribution License.

\section{ABSTRACT}

The objective of this study was to explore and describe the experiences of health care providers managing sexual assault victims in the emergency unit of a community hospital in the Nkangala district in the Mpumalanga Province. A qualitative, phenomenological design was applied. Purposeful sampling was used to select participants from health care providers who were working in the emergency unit and had managed more than four sexual assault victims. Data were collected by means of individual interviews and analysed according to the Tesch method of data analysis by the researcher and the independent co-coder. Main categories, subcategories and themes were identified. Participants expressed their emotions, challenges and police attitudes and behaviours, as well as inconsistencies in guidelines and needs identification. It was recommended that members of the multidisciplinary team engage in community activities and that the community participate in matters pertaining to sexual assault. Government should develop clear guidelines that are applicable to rural and urban South Africa. Health care sciences should aim to train more forensic nurses. All relevant departments should work together to alleviate the complications caused by sexual assault incidents.

\section{OPSOMMING}

Die doel van hierdie studie was om die ervaringe van gesondheidsorgverskaffers wat slagoffers van seksuele aanranding in die ongevalle-eenheid van 'n gemeenskapshospitaal in die Nkangala-distrik in die provinsie van Mpumalanga hanteer, te ontgin en te beskryf. ' $n$ Kwalitatiewe fenomenologiese ontwerp is toegepas. Doelbewuste steekproefneming is gebruik om deelnemers te selekteer uit die groep gesondheidsorgverskaffers wat in die ongevalle-eenheid werksaam was en meer as vier slagoffers van seksuele aanranding hanteer het. Data is by wyse van individuele onderhoude ingesamel en volgens die Tesch-metode van data-analise deur die navorser en die onafhanklike medekodeerder geanaliseer. Hoofkategorieë, subkategorieë en temas is geïdentifiseer. Deelnemers het uitdrukking gegee aan hulle emosies, uitdagings, die houding en gedrag van polisiebeamptes, teenstrydighede in riglyne en behoefte-identifikasie. Aanbevelings is dat multidissiplinêre spanlede betrokke moet wees by gemeenskapsaktiwiteite en dat die gemeenskap moet deelneem aan sake wat verband hou met seksuele aanranding. Die regering moet duidelike riglyne ontwikkel wat op landelike en stedelike Suid-Afrika van toepassing is. Gesondheidsorgwetenskappe moet daarop gerig wees om meer forensiese verpleegkundiges op te lei. Alle toepaslike departemente moet saamwerk om die komplikasies te verlig wat deur voorvalle van seksuele aanranding veroorsaak word.

\section{INTRODUCTION}

The study of the experiences of health care providers managing sexual assault victims in an emergency unit was conducted according to the research methodology discussed in Part 1 of this article. In this part, the results are discussed and the literature control is conducted. Data from the transcripts of interviews held with health care providers who managed sexual assault cases in the emergency unit of the selected hospital in the Nkangala district in the Mpumalanga Province were analysed in accordance with Tesch's method of data analysis, as discussed by Clark and Cresswell, cited by Lehana and Rhyn (2003:29). Distinct themes, categories and subcategories were established from the transcripts. The themes were thoroughly investigated in order to discover their important features as well as the manner in which the data should be organised and interpreted. A literature control was conducted as a further measure to enhance the trustworthiness of the findings of the study.

\section{RESULTS AND LITERATURE CONTROL}

Five main categories were identified and 13 subcategories developed in this study. Data obtained from the interview transcripts and field notes were grouped according to the relevant subcategories under the identified categories. See Table 1 on the framework of the data analysis.

\section{Emotions}

Under the category emotions, the following two subcategories were established: emotions related to the participants and emotions related to the sexual assault survivors.

\section{Emotions related to the participants}

In the subcategory regarding participants' emotions, the following themes were discovered: empathy, emotional trauma, anger, fear and judgmentalism. Participants experienced the power of identifying with the victims of sexual assault when managing them in the emergency unit. This is illustrated by the following quotes: 
TABLE 1

Framework of the data analysis

\begin{tabular}{|c|c|c|}
\hline MAIN CATEGORIES & SUBCATEGORIES & THEMES \\
\hline \multirow[t]{2}{*}{ 1. EMOTIONS } & - $\quad$ Participants & $\begin{array}{ll}\cdot & \text { Empathy } \\
\cdot & \text { Emotional trauma } \\
\cdot & \text { Judgmentalism } \\
\cdot & \text { Anger } \\
\text { - } & \text { Fear }\end{array}$ \\
\hline & - $\quad$ Sexual assault victims & $\begin{array}{ll}\cdot & \text { Emotional trauma } \\
\cdot & \text { Stigmatisation }\end{array}$ \\
\hline \multirow[t]{4}{*}{ 2. CHALLENGES } & - Workload & $\begin{array}{ll}\cdot & \text { Overworked } \\
\cdot & \text { Distribution of work }\end{array}$ \\
\hline & - Time constraints & $\begin{array}{ll}\cdot & \text { Lengthy consultation } \\
\cdot & \text { Reporting of the sexual assault case }\end{array}$ \\
\hline & - $\quad$ Communication problems & $\begin{array}{ll}\text { - } & \text { Lack of community education } \\
\text { - } & \text { Lack of interdisciplinary communication }\end{array}$ \\
\hline & - Lack of trained personnel & $\begin{array}{ll}\text { - } & \text { Handful of trained forensic nurses } \\
& \text { Lack of skills and techniques }\end{array}$ \\
\hline \multirow[t]{2}{*}{ 3. POLICE ATTITUDES AND BEHAVIOUR } & - Violation of privacy & $\begin{array}{l}\text { - } \quad \text { Disregard for victims' rights } \\
\text { - } \quad \text { Lack of empathy }\end{array}$ \\
\hline & - $\quad$ Police impatience & - Lack of support \\
\hline 4. INCONSISTENT GUIDELINES & - Provincial discrepancy & $\begin{array}{ll}\text { - } & \text { Different structures } \\
\text { - } & \text { Varied functions }\end{array}$ \\
\hline 5. NEEDS IDENTIFICATION & $\begin{array}{l}\text { - } \quad \text { Central services } \\
\text { - } \quad \text { Community education } \\
\text { - } \\
\text { - } \quad \text { Pore personnel } \\
\end{array}$ & $\begin{array}{ll}\text { - } & \text { Need for a trauma centre } \\
\text { - } & \text { Need for community education } \\
\text { - } & \text { Need for more female doctors } \\
\text { - } & \text { Need for more forensic nurses } \\
\text { - } & \text { Need for separate consultation rooms } \\
\text { - } & \text { Need for privacy during examination }\end{array}$ \\
\hline
\end{tabular}

'And as much as being a male and the offender was also a male, having to examine the area that was offended by the male one needs to deal with that before one starts to examine the patient because that can trigger the traumatic experience that she has had.'

'You see a two-year-old being sexually assaulted and at home you have a two-year-old, you feel traumatised.'

'As a health professional I try to be objective as possible but when you see an old lady raped you think of your own mother.'

'Sometimes as a parent it affects me emotionally because I have children of my own."

In Odentaal, Shaetzing and Kruger (2001:224), the above themes are supported. They state that a perceived lack of concern and insensitivity can demoralise the survivors during this sensitive stage of rehabilitation. Brouwer (2005:838) stresses the importance of giving medical officers the choice of participating in the management of sexual assault survivors as the task is a traumatic one and forcing a person to do it may make that person lose interest in sexual assault victims. Goldenring and Alfred (2001:1169) cite Smugar, Spina and Merz (2000) as stating that practitioners can be exposed to trauma, especially when a sexual assault victim sues them for malpractice. Thus health care providers are also subjected to secondary victimisation. In this study, participants indicated that health care providers judged those victims who were treated for sexual assault while under the influence of alcohol. This is supported by the study conducted by Wood (2005:310), which states that girls who were seen hanging out in taverns were thought to be signalling their availability. However, Odentaal et al. (2001:22) emphasise the importance of giving the victims the benefit of the doubt.

Emotions related to the sexual assault survivors

Participants not only expressed their own feelings but also those of the victims while under the care of health care providers in the emergency unit. In the 'subcategory emotions of the victims', participants in the study indicated that victims of sexual assault were subjected to emotional trauma and stigmatisation. Goldenring and Alfred (2001:1169) support this and state that private and stigmatising information about rape is aired especially during trial. In King et al. (2004:683), it is noted that rape could cause depression, anxiety or posttraumatic disorders, which may result in alcohol abuse, tobacco consumption or suicidal behaviour.

'I have observed that when a female victim is attended to by the male practitioner they become very tense.'

'These people they are suffering, they suffer anywhere they go, at the school, at the police station, even here at the hospital.'

\section{Challenges}

Participants indicated that they experienced certain challenges when managing sexual assault victims in the emergency unit Under the category challenges, four subcategories emerged: workload, time constraints, communication problems and lack of trained personnel.

\section{Workload}

Participants expressed concern about the amount of work done by an individual practitioner when managing victims of sexual assault. In this subcategory, the following themes were identified: being overworked and the distribution of work. Participants felt that the work was not distributed equally among the members of the multidisciplinary team and that they were overworked. Martin (2002:106) states that any omission in medical evidence as a result of excessive workload cannot be rectified and could lead to the withdrawal of cases. In a study conducted by Brouwer (2005:838), health care providers stated that it was difficult to examine sexual assault victims in a busy primary health care unit. Ciancone, Wilson, Collete and Gerson (2000:353) report that respondents failed to participate in a study that was meant for forensic nurses, probably due to workload or time availability. The following quotes explicate 
the theme:

'So, if a doctor has a queue of more than 20 patients waiting for him outside, being alone, it really presses on him to do what he does so that he can attend to the queue.'

'Doctors are always in a hurry.'

'Everybody has a common thing, you know, that is, in a public sector, there is a shortage of staff.'

\section{Time constraints}

Participants expressed experiencing problems with the time it takes to manage sexual assault victims. Under the subcategory time constraints, the following themes were identified: lengthy consultation and reporting of the sexual assault case. Du Mont and Parris (2004:527) support this finding: Respondents in that study stated that collecting evidence and testifying in court were their most time-consuming duties. According to Feldhaus, Houry and Kaminsky (2000:27), nearly half of adult sexual assault victims do not report the sexual assault to the police or seek medical care in time or both because of the fear of public embarrassment or disclosure. This supports the finding that victims do not report sexual assault incidents in time. This theme is supported by the following quotes:

'It is a fairly lengthy process to consult with the sexual assault victim.'

'Proper examination of the sexual assault victim takes about an hour.'

'It is time-consuming and other patients should wait in the queue.'

'It takes a lot of time for the sexual assault case to open up to a male practitioner.'

\section{Communication problems}

This subcategory consists of participants' expressions of concern about communication constraints experienced during the management of sexual assault cases. Two themes were identified in this subcategory: lack of community education and lack of interdisciplinary communication. This finding is in line with the suggestion by Smugar et al. (2000:1372) that police officers and emergency medical services be made aware of hospital practices before bringing survivors of sexual assault to hospital. Different communication media should be used to make the community aware of the procedures surrounding the management of sexual assault victims. This theme is supported by the following quotes:

'Our community is not informed; most of the women we see have already taken a bath.'

'The police don't communicate ... [with] us prior [to] bringing the victims to the emergency unit, thus sometimes they find that the doctor is not available and they have to wait long.'

'There is poor communication between the health care workers and police officers in terms of priority emergency that such cases hold.'

\section{Lack of trained personnel}

Participants indicated that there was a shortage of trained personnel to manage sexual assault victims. The following themes were identified under this subcategory: handful of forensic nurses and lack of skills and techniques. Martin (2002:106) supports this finding and suggests that the training of medical sexual assault examiners should be formalised and recognised through incentives. In a study conducted by Brouwer (2005:838), approximately half of the participants stated that they would prefer to receive training in the management of sexual assault by an experienced person who examines the victims of rape on a regular basis. The training of forensic nurses is taking place but is not regulated by the South African Nursing Council (SANC) and no incentives for this training exist. The following quotes support the theme:
'The only trained forensic nurse works during the day, yet most sexual assault victims report at night.'

'We as ordinary nurses cannot do the duties of the forensic nurse such as collecting evidence and filling in the J88 form.

'I mean the last time I learnt about sexual assault I was at school and there are a lot of changes that have happened since then.'

\section{Police attitudes and behaviour}

Under the category police attitudes and behaviour, two subcategories emerged: violation of privacy and police impatience.

\section{Violation of privacy}

Participants stated that members of the South African Police Service (SAPS) violated the privacy of the sexual assault victims when accompanying them to the emergency unit. Participants felt that members of the SAPS did not take human rights into consideration and did not show empathy to the victims of sexual assault. According to Koss (2005:106), the approach of the current justice system to sexual assault generally does not serve the victims well. Koss (2005:105) also notes that studies of the attitudes and behaviour of police officers, prosecutors and judges have led to some changes and upgrades in training within the criminal justice system, although little improvement has been seen. The Department of Health (2004:3) finds that many sexual assault victims do not go to the police because of the perception that reporting the crime is unlikely to result in punishment for the perpetrator. This theme is supported by the following quotes:

'They are brought in by the police officers who will be talking to other patients in the queue; their privacy is violated.'

'Nowadays when you see a female patient accompanied by the police officer who is carrying a crime kit people know that she has been sexually violated.'

'In most cases the police don't cover the crime kit and confidentiality is lost.'

'They carry it, the crime kit, just like a nice flower.'

\section{Police impatience}

The participants stated that they had sensed a lack of patience from the police officers accompanying sexual assault victims to the emergency unit. Under this subcategory, the theme lack of support for victims was identified. This finding is in line with the findings of Usdin, Scheepers, Goldstein and Japhet (2005:2435). In a study conducted by these authors, women revealed frustration with the existing legislation and police reluctance to assist. This theme is supported by the following quotes:

'Police are always in a hurry to get to the police station despite explaining to them that the examination takes long.'

'Police don't seem to acknowledge or have patience for one to focus on the rape case.'

'When they arrive in casualty they think that everything should come to a standstill and [they should] be attended to.'

'Police think that we undermine their work if we don't attend to them soon.'

\section{Inconsistent guidelines}

In this category, the participants stated that they had experienced an inconsistency in the guidelines for managing sexual assault victims. The subcategory provincial discrepancy emerged under this category.

\section{Provincial discrepancy}

Two themes emerged from the subcategory provincial discrepancy: different structures and varied functions. The participants felt that the structures in place for the management of sexual assault victims were not the same in all provinces and 
that they were expected to perform varied functions. This was illustrated as follows:

'Now the bad thing is we are supposed to work like in other provinces that I have been but here it is different.

'In other provinces, they have victim support units and the procedure is done in less than 10 minutes'.

According to Du Mont and Parris (2004:516), medical practitioners who treat sexual assault cases are expected to be able to function across professional boundaries. Their activity is at the intersection of medicine and law, where medical professionals are employed in the service of the court as experts, not only in patient care and treatment but also in the collection and evaluation of medical forensic evidence for judicial purpose. Martin (2002:107) states that the unsatisfactory situations that medical practitioners have been exposed to have led to the development of several proposals for the management of sexual assault victims. Smugar et al. (2000:1372) suggest that institutions should re-evaluate their policies with regard to sexual assault management and if they fail to do so, state legislation requiring hospitals to meet certain standards of care for the treatment of rape victims would be appropriate.

The South African government compiled the National Management Guidelines for Sexual Assault Care in order to meet these minimum acceptable standards (Department of Health 2004:4). These management guidelines aim to improve sexual assault care within the framework of a health care service mode in which the patients' health needs are central. The guidelines form part of sexual assault policy development, focusing on the implementation of the policy framework wherever appropriate, and will facilitate the provision of high-quality care for sexual assault victims (Department of Health 2004:1). However, these guidelines are applied only in some provinces.

\section{Needs identification}

Under the category needs identification, four subcategories emerged: centralised services, community education, more personnel and privacy.

\section{Central services}

Participants felt that sexual assault victims would receive better care in a trauma centre with a dedicated district surgeon and forensic team. The training and development of medical practitioners in the medico-legal examination of a rape victim can only be successful in an environment conducive to learning. Such an environment can only be created in a well-equipped centre with devoted staff members who want to be involved in the management of rape cases (Brouwer 2005:838). According to Martin (2002:108), victims of sexual assault should be seen in a centre that has the capacity to manage all their needs in a holistic manner. This theme is exemplified by the following quotes:

'I feel that the district surgeon must be employed who will deal with sexual assault cases because in most cases casualty is so busy and police have to wait.'

'If somebody like a district surgeon is employed to just do that job, they will make sure that they get updated with new information around sexual assault issues.

"There is a need for a full forensic team to deal with sexual assault cases.

'Sexual assault is not only about giving prophylaxis; for these cases to be treated properly, we need to have a multidisciplinary team.'

\section{Community education}

Participants expressed the need for community education. According to King et al. (2004:689), comprehensive approaches that adopt a public health care approach to preventing rape as well as forms of risk behaviour are also needed. During the literature review of community education, it was discovered that the government of South Africa has put programmes in place to educate the community. Examples are Khomanani as well as the Soul City vehicle that was developed by the Soul City Institute for Health and Development Communication. This vehicle consists of primetime radio and television drama and print material (Usdin et al. 2005:2435). The following quotes support the theme:

"The community need to be educated regarding sexual assault issues.'

'About $40 \%$ to $50 \%$ of women keep quiet about it.'

'People need to be taught about their rights.'

'People need to know that sexual assault is a serious crime irrespective of the consequences.'

\section{More personnel}

Participants expressed the need for more female doctors and the need for more forensic nurses. The need for female practitioners is supported by Odentaal et al. (2001:227), who state that it is of paramount importance to have a chaperone present or to accommodate a female friend during the examination in order to offer support to the victim. Chasson and Russell (2002:594) support the use of forensic nurses to examine sexual assault victims as it has been found that most victims who report to the emergency unit do not have injuries that meet the definition of an emergency medical condition. Ciancone et al. (2000:354) affirm that, over the past two decades, forensic nurse examiners in the United States of America (USA) have become increasingly important in the management of sexual assault victims. The programme that has been implemented was designed to remove the management of sexual assault cases from the emergency unit in order to create a compassionate examination process and obtain complete, consistent data. Hutson (2002:86) notes that since the introduction of sexual assault nurse examination (SANE) programmes, law enforcement officers have found that evidence is collected more efficiently and consistently, providing agencies with better evidence to move the case forward to the prosecution. This theme is exemplified by the following quotes:

'More nurses should be sent for forensic nursing training.'

'It is usually difficult for a patient to open up to a male doctor with regard to their experiences but they are ready to open up to the sister.

'The sexual assault cases who are attended to by the medical officer do not get quality care because doctors are always in a hurry.

'Sometimes the doctor is so busy he even forgets to greet the patient but then expects the patient to open up.

\section{Privacy}

The need for separate consulting rooms and the need for privacy during examination, identified by the participants, are in line with Esposito's (2006:71) statement that the examination of sexual assault victims should be done in a private setting (without residents or students present), using a nonjudgmental, culturally competent approach. According to Hutson (2002:85), an ideal SANE room should be private and not located in the middle of the large emergency unit; further recommendations are that the room should be used only for SANE examinations. The following quotes support the theme:

'I feel like I'm invading somebody's privacy, but the most important thing is to put the patient at ease; any part that is not dealt with, cover it up.'

'Sexual intercourse is a very private thing; it is something not easy to talk about.'

'Sexual assault cases need to be attended to privately, in a private place, away from other casualty patients.'

\section{RECOMMENDATIONS}

Based on the results of the study, the following recommendations are made: 
- All relevant departments should participate in strengthening rape prevention campaigns in the community

- Forensic nursing training should be recognised as scarce skills by the SANC

- A protocol according to which forensic nurses manage sexual assault victims should be implemented in all provinces

- Professional nurses with experience in obstetrics and gynaecology should be recruited to train as forensic nurses

- Effective and efficient employee support programmes and institutional structures should be put in place in order to assist employees to cope with the demands of managing sexual assault victims

- Social support should be strengthened at community level with the involvement of members of the multidisciplinary team

- A repatterning of culture should take place in order to assist women and children to talk freely about sexual issues

- Further research should be conducted on the attitudes and behaviours of police officers and other members of the interdisciplinary team

- Further research should be conducted on the effectiveness of the National Guidelines in rural areas.

\section{LIMITATIONS}

Limitations of the study include the small, purposefully selected sample, which may affect the capacity to detect statistically significant differences in the data. Since the study was conducted in only one district hospital, the results cannot be generalised to other hospitals. The time that had elapsed after examining the sexual assault victim was not taken into consideration by the researcher. If the health worker attended the victim a long time ago, experiences by the health worker would have faded as opposed to experiences by the health worker who attended the victim within the previous week. The inclusion and the exclusion criteria of the participants posed some limitations because doctors stated their experiences and nurses also stated their experiences. The author used the concept health workers in some instances inclusively and in some instances exclusively. The author did not indicate the assumptions on which the study was based.

\section{CONCLUSION}

Sexual assault is unfortunately a common occurrence in our society and has far-reaching consequences for the individual victim as well as society as a whole. Although this kind of assault is referred to specifically as sexual assault, the assault affects every aspect of the victim. During the course of the study, it emerged that the management of sexual assault survivors requires a multidisciplinary approach and should be undertaken by a team of professionals from the Department of Health, the Department of Social Services, the Department of Education, the Department of Justice, the Department of Safety and Security and other relevant departments, as well as, and not least, the community. Sexual assault should be managed at all levels of care: at a preventative level, where health education plays a big role, at a secondary level, where victims are treated as soon as possible after being sexually assaulted, and at a rehabilitative level, where health care providers need to restore hope to victims who are emotionally traumatised and to other health care providers who are emotionally affected by the management of sexual assault victims. With its focus of holistic patient care, the nursing profession is an ideal discipline to take the lead in matters concerning sexual assault.

\section{REFERENCES}

Brouwer, I.J., 2005, 'Training and development needs of medical practitioners involved in the medico-legal examination of survivors of sexual assault', South African Medical Journal 99(11), 837-838.
Chasson, S. \& Russell, A., 2002, ‘Do SANE examinations satisfy the EMTALA requirement for "medical screening"?' Journal of Emergency Nursing 28, 593-595.

Ciancone, A.C., Wilson, C., Collete, R. \& Gerson, L.W., 2000, 'Sexual assault nurse examiner programs in United States', Annals of Emergency Medicine 35(4), 353-357.

Department of Health, 2004, National management guidelines for sexual assault care, Government Printers, Pretoria.

Du Mont, J. \& Parris, D., 2004, 'The doctor's dilemma: Care giving and medico-legal evidence collection', Journal of Medicine and Law 23, 515-529.

Esposito, N., 2006, 'Women with history of sexual assault: Healthcare visit can be a reminder of a sexual assault', Advanced Journal of Nursing 106(3), 69-73.

Feldhaus, K.M., Houry, D. \& Kaminsky, R., 2000, 'Life sexual assault prevalence rates and reporting in an emergency department population', Annals of Emergency Medicine 36(1), 23-27.

Goldenring, J. \& Alfred, G., 2001, 'Post-rape care in hospital emergency rooms', American Journal of Public Health 36(3), 1169-1170.

Hutson, L.A., 2002, 'Development of sexual assault nurse examiner programs', Emergency Nursing 37(1), 79-88.

King, G., Flisher, A.J., Noubary, F., Reece, R., Marais, A. \& Lombard, C., 2004, 'Substance abuse and behavioural correlates of sexual assault among South African adolescents', Journal of Child Abuse and Neglect 28, 683-689.

Koss, M.P., 2005, 'Empirical enhanced reflections on 20 years of rape research', Journal of Interpersonal Violence 20(1), 100-107.

Lehana, T.V. \& Rhyn, L., 2003, 'Phenomenological investigation of experiences of pregnancy by unmarried adolescents in Maseru', Health SA Gesondheid 18(1), 26-37.

Martin, L.J., 2002, 'Forensic evidence collection: South African perspective', International Journal of Gynaecology and Obstetrics 78 (suppl. 1), 105-110.

Odentaal, H.I., Schaetzing, A.E. \& Kruger, T.F., 2001, Clinical gynaecology, 2nd edn., Juta, Pretoria.

Smugar, S.S., Spina, B.J. \& Merz., F.E., 2000, ‘Informed concern for emergency contraceptives variability in hospital care of rape', American Journal of Public Health 9, 1372-1575.

Usdin, S., Scheepers, E., Goldstein, S. \& Japhet, G., 2005, 'Achieving social change on gender based violence: A report on the impact evaluation of Soul City's fourth series', Social Science and Medicine 61, 2434-2445.

Wood, K., 2005, 'Contextualizing group rape in post-apartheid South Africa', Culture, Health and Sexuality 7(4), 303-317. 